\title{
Laku Pandai's Program And Deposit Funds: Study At Bank Of BRI Sharia
}

\author{
M. Nur Rianto Al Arif ${ }^{1}$, Firmansyah ${ }^{2}$ \\ ${ }^{1}$ UIN Syarif Hidayatullah Jakarta, ${ }^{2}$ Uhamka \\ ${ }^{1}$ mnur.rianto@uinjkt.ac.id, ${ }^{2}$ syahfirman584@gmail.com
}

\begin{abstract}
Laku Pandai's program is one of the policies that implemented by the financial service authority (OJK) to expand the banking service to the people. One of the Islamic banks that had implemented the program is Bank of BRI Sharia. This research is going to examine the effectiveness of Laku Pandai's program to deposit funds in Bank of BRI Sharia. This study using regression with the dummy variable. The result shows that there is a difference between pre and post-Laku Pandai's program in Bank of BRI Sharia. This result implies that the Laku Pandai's implementation had an impact on increasing deposit funds in Bank of BRI Sharia. So, it is recommended to add more Islamic banks that implemented the Laku Pandai's program
\end{abstract}

Keyword: Laku Pandai's program, deposit funds, multiple regressions

\begin{abstract}
Abstrak: Program Laku Pandai merupakan salah satu kebijakan yang dikeluarkan oleh otoritas jasa keuangan (OJK) untuk memperluas layanan perbankan kepada seluruh lapisan masyarakat. Salah satu bank syariah yang telah menerapkan program Laku Pandai ialah Bank BRI Syariah. Penelitian ini bertujuan untuk menguji efektivitas program Laku Pandai terhadap penghimpunan dana pihak ketiga di bank BRI Syariah. Adapun teknik analisis yang dipergunakan ialah regresi berganda dengan variabel dummy. Hasil penelitian menunjukkan bahwa terdapat perbedaan dana pihak ketiga antara sebelum dan sesudah penerapan program Laku Pandai di Bank BRI Syariah. Hal ini menunjukkan bahwa penerapan program Laku Pandai di Bank BRI Syariah telah mampu meningkatkan dana pihak ketiga. Oleh karenanya penelitian ini merekomendasikan untuk lebih banyak lagi bank syariah yang menerapkan program Laku Pandai.
\end{abstract}

Kata Kunci: program Laku Pandai, dana pihak ketiga, regresi berganda.

\section{INTRODUCTION}

To extend the banking services to all levels of society, financial service authority (FSA/OJK) launched the program of Laku Pandai (Layanan Keuangan Tanpa Kantor dalam rangka Keuangan Inklusif) since 2015. Initially, the program was followed by six banks, such as Bank of Mandiri, Bank of BRI, Bank of BNI, Bank of BTN, Bank of BTPN, and Bank of BCA. Along with the development, until the end of 2016, there have been 12 conventional banks and one full-fledged Islamic banks that have joined the Laku Pandai's program.

This research will examine the effectiveness of Laku Pandai's program between pre and post-program in Bank of BRI Sharia. Bank of BRI Sharia becomes the object of this study because it is the only full-fledged Islamic banks that follow the Laku Pandai's program. The findings of this research obtained indicate that there are differences of deposit funds between before and after the implementation of Laku Pandai's program in Bank of BRI Sharia. Therefore, the findings of this study are in line with the objectives of the Laku Pandai's program that to extend the financial services to all levels of society. 
The financial service authority launched the Laku Pandai's program because it sees on the condition in Indonesia. There are still many Indonesian people who do not know banking services, either for saving or get loan facility. The banking services in Indonesia still do not reach all areas in Indonesia, especially in remote locations. This problem arises because the cost incurred for the opening the branch office in remote regions, such as rental cost, administration cost, human resources cost, technology cost, etc. This problem makes a lot of Indonesian people still not touchable to the banking services.

Based on data from Bank Indonesia, to serve 250 million Indonesians, banks are more focused on building branch offices. The banking services in Indonesia have 18,000 branches, 7,000 ATM's machines, and 4,000 rural bank's offices. Based on the number of services, it is only able to serve $20 \%$ of the society or only 30 million of productive people. This fact is very left behind if compared with neighboring countries, such as Malaysia or Thailand. The main issues are the portion of office opening investment is higher than the expansion of access to information technology. Thailand with 33 commercial banks and 56,000 branches can reach $73 \%$ of productive people. Malaysia with 15,000 branches can reach 66\% of productive people (Prasetyo, 2015).

The fact also supported with the data from World Bank: Global Financial Inclusion Index (Findex) in 2011, which is only $19.5 \%$ of people in Indonesia that had an account in banks. If we compare with neighboring countries such as: Malaysia (66.7\%), Thailand (77.7\%), China (63.8\%), Brazil (55.9\%), Rusia (48.2\%), Philippines (26.5\%), and Vietnam $(21.4 \%)$.

Table 1. Number of Adult People That Have Account in Bank

\begin{tabular}{cc}
\hline Countries & Percentage (\%) \\
\hline Thailand & $77.7 \%$ \\
Malaysia & $66.7 \%$ \\
China & $63.8 \%$ \\
Brazil & $55.9 \%$ \\
Rusia & $48.2 \%$ \\
Philipines & $26.5 \%$ \\
Vietnam & $21.4 \%$ \\
Indonesia & $19.6 \%$ \\
\hline Source: World Bank: Global Financial Inclusion Index (Findex)
\end{tabular}

According to the financial literacy national survey by financial service authority in 2013 , the literation index in Indonesia to banking industry shows the number $22 \%$. This figure means that in every 100 Indonesian people, only 22 people that had knowledge and confidence with the banking products. From the same survey, we can also get the result of utility index of banking products and services. The result shows the number of 57\%; it means only 57 of 100 people had utilized banking products and services. From financial service authority survey shows that almost Indonesian people used the products and services in banking without adequate understanding.

Based on these data, it can say that the access to Indonesian society to financial institutions is still small. There needs to be a breakthrough for banking services to reach more Indonesians people. One of the breakthroughs is by branchless banking. The branchless banking is suitable with the vision of National Strategy for Financial Inclusion (NSFI) by Bank of Indonesia that launched in 2012. The NSFI's program is to achieve the 
financial inclusive that had developed by the government. These strategies also realized by the financial service authority to banking and financial industry. The inclusive financial means that the condition, which all of the people can reach the financial access service with quickly. Besides that the financial inclusive means that the people had a tradition to optimize the utilization of financial services.

The Laku Pandai's program is the extension of branchless banking programs. The branchless banking's program is non-office bank services. This program is not using offices networking, but using information technology in its operation. This program requires cooperation from other parties, namely the agent, which is an extension of the bank to give the financial services to the people. The target of this program is people who do not know, use, and/or obtain the banking and other financial services. According to the Bank of Indonesia, the non-office services is the concept of banking service providers outside the conventional form in general, both by using information communication and technology services, or, by using the third parties involvement.

Table 2. The Development of Laku Pandai. 2015-2016

\begin{tabular}{|c|c|c|c|c|c|c|c|}
\hline & \multicolumn{3}{|c|}{2015} & \multicolumn{4}{|c|}{2016} \\
\hline & June & September & December & March & June & September & December \\
\hline \multirow{2}{*}{$\begin{array}{l}\text { Number of } \\
\text { Banks }\end{array}$} & $6 \mathrm{BUK}$ & $6 \mathrm{BUK}$ & $7 \mathrm{BUK}$ & $9 \mathrm{BUK}$ & 12 BUK \& & 14 BUK \& & 18 BUK \& \\
\hline & & & & & 1 BUS & 2 BUS & 2 BUS \\
\hline \multirow{2}{*}{$\begin{array}{l}\text { Number of } \\
\text { agent / } \\
\text { outlet }\end{array}$} & 3,734 & 19,411 & 60,805 & 84,374 & 104,707 & 160,490 & 275,916 \\
\hline & Agent & Agent & Agent & Agent & Agent & Agent & Agen \\
\hline $\begin{array}{l}\text { Number of } \\
\text { clients }\end{array}$ & $\begin{array}{l}35.984 \\
\text { clients }\end{array}$ & $\begin{array}{r}1.061 .076 \\
\text { clients }\end{array}$ & $\begin{array}{r}1.216 .952 \\
\text { clients }\end{array}$ & $\begin{array}{r}1.351 .798 \\
\text { clients }\end{array}$ & $\begin{array}{r}1.626 .068 \\
\text { clients }\end{array}$ & $\begin{array}{r}1.949 .005 \\
\text { clients }\end{array}$ & $\begin{array}{r}3.700 .215 \\
\text { clients } h\end{array}$ \\
\hline \multirow{4}{*}{$\begin{array}{l}\text { Number of } \\
\text { outstanding } \\
\text { funds } \\
\text { Number of } \\
\text { province }\end{array}$} & IDR 2.9 & IDR 40 & IDR 67 & IDR 50 & IDR 63 & IDR 93 & IDR 216.5 \\
\hline & Billion & Billion & Billion & Billion & Billion & Billion & Billion \\
\hline & 30 & 33 & 34 Provinsi & 34 & 34 & 34 & 34 \\
\hline & Province & Province & Province & Province & Province & Province) & Province \\
\hline \multirow{4}{*}{$\begin{array}{l}\text { Number of } \\
\text { District/ } \\
\text { City }\end{array}$} & 211 (of & 368 (of & 385 (of & 427 (of & 499 (of & 499 (of & 507 (of \\
\hline & 514 & 514 & 514 & 514 & 514 & 514 & 514 \\
\hline & District/Cit & District/Cit & District/Cit & District/Cit & District/Cit & District/Cit & District/Ci \\
\hline & $\mathrm{y})$ & $\mathrm{y}$ & $\mathrm{y}$ & $\mathrm{y}$ & $\mathrm{y}$ & $\mathrm{y}$ & $\mathrm{y}$ \\
\hline
\end{tabular}

Source: Financial Service Authority

*) Note: BUK is Conventional banks; BUS is full-fledged Islamic banks

According to the Table 2, we can see that the numbers of the agent (either individual or group) had increased significantly. Besides that, there is also an increase in numbers of outstanding funds in each month. According to the data, we can see the diversity of Laku Pandai's agents still concentrated in Java. The data imply that the agent's diversity still not equal to the outside of Java, such as: in Maluku, Sumatera, Kalimantan, and Sulawesi.

Bank of BRI Sharia is the first full-fledged Islamic bank that had implemented the Laku Pandai's program. This program is suitable with the inclusive financial goal from the government. Bank of BRI Sharia named this program as BRIS-SMART, and the agents are called as temanBRIS. The customers can open the account at the nearest temanBRIS with the accounts number as same as with their cell phone numbers. Besides that, the customer can also conduct deposit, withdrawals and transfer transaction in agents. There 
are no minimum balance, free administrative fees, and the availability of mobile banking applications for the customers.

Figure 1. The Growth of Deposit Funds. 2014-2016

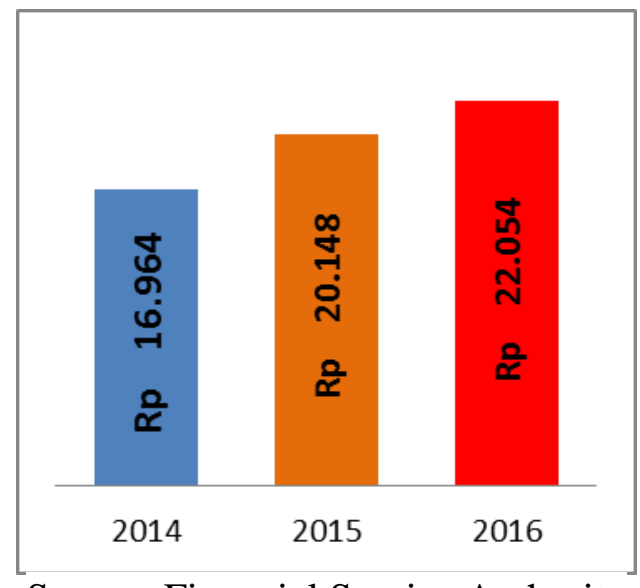

Source: Financial Service Authority

After the program implementation, Bank of BRI Sharia has obtained 859 customers and 284 agents (until the end of 2016). The number of customers and agents is expected to increase in the future. The number of deposit funds has grown after the program's implementation (see Figure 1). The branchless banking program does not require the establishment of a branch office but requires the cooperation with a third party (agents). Besides that, the program also needs a good telecommunication network and the promotion cost.

Sarah (2015) said that there are several elements should consider by the banks to implement the branchless banking programs (such as Laku Pandai's program). First, the capital aspect becomes an early consideration when implementing this program. This will useful to measure the capital ability to close the loss potential. The efficiency issue will be the second element for banks' consideration. The efficiency will measure the ability of banks' management in control the operational cost.

\section{METHOD}

This research is using the quantitative method with time series data. The method that used in this research is multiple linear regression with the dummy variable. This study aims to analyze the impact of Laku Pandai's program to the deposit funds. The data that used in this research is quarterly financial reports from 2009-2016. The mathematical equation that applied in this study can be seen as follows:

$$
\mathrm{LnDPK}_{\mathrm{t}}=\alpha+\beta_{1} \mathrm{D}_{-} \mathrm{LP}_{\mathrm{t}}+\beta_{2} \mathrm{CAR}_{\mathrm{t}}+\beta_{3} \mathrm{BOPO}_{\mathrm{t}}+\varepsilon_{\mathrm{t}}
$$

Where: Ln DPK is natural log of deposit funds; D_LP is dummy of Laku Pandai's program; Which: $0=$ before; $1=$ after; CAR is capital adequacy ratio BOPO is operational efficiency ratio

This research did the classical assumption test, such as normality test, heteroscedasticity test, multicollinearity test, and autocorrelation test. This classical assumption test to make sure that the BLUE (best linear unbiased estimator) criteria can be 
achieved. After that, we will do the hypothesis test, which includes: the t-test, F-test, and determination coefficient (adjusted R-square).

\section{RESULT AND DISCUSSION}

Result. The first test we had done in this research is the classical assumption tests, which is includes: normality test, heteroscedasticity test, multicolliniearity test, and autocorrelation test. The normality test with using Kolmogor-Smirnov test shows that the data had normally distributed (see Table 3 ).

Table 3. The Normality Result

\begin{tabular}{|c|c|c|}
\hline & & Unstandardized Residual \\
\hline $\mathrm{N}$ & & 32 \\
\hline \multirow{3}{*}{ Normal Parameters ${ }^{\mathrm{a}, \mathrm{b}}$} & Mean & ,0000000 \\
\hline & Std. Deviation & 46694946 \\
\hline & Absolute & ,202 \\
\hline \multirow[t]{2}{*}{ Most Extreme Differences } & Positive &, 115 \\
\hline & Negative &,- 202 \\
\hline Kolmogorov-Smirnov Z & & 1,140 \\
\hline Asymp. Sig. (2-tailed) & & 148 \\
\hline
\end{tabular}

Source: SPSS Result.

The next classical assumption test is heteroscedasticity test. According Table 4 shows that there is no heteroscedasticity problem in this model. Table 5 shows the multicolliniearity test. The result shows that the value of VIF for each variable is 1.034, 1.054, and 1.055. This result implies that there is no multicolliniearity in this model.

Table 4. The Heteroscedasticity Result

\begin{tabular}{|c|c|c|c|c|c|c|}
\hline & & & $\begin{array}{l}\text { D_laku } \\
\text { Pandai }\end{array}$ & CAR & BOPO & $\begin{array}{c}\text { Unstandardize } \\
\text { d Residual }\end{array}$ \\
\hline \multirow{12}{*}{$\begin{array}{l}\text { Spea } \\
\text { rman' } \\
\text { s rho }\end{array}$} & \multirow{3}{*}{ DLakuPandai } & Correlation Coefficient & 1,000 & ,009 &,- 182 &,- 117 \\
\hline & & Sig. (2-tailed) & & 960 & ,319 &, 525 \\
\hline & & $\mathrm{N}$ & 32 & 32 & 32 & 32 \\
\hline & \multirow{3}{*}{ CAR } & Correlation Coefficient & ,009 & 1,000 &, 066 & 038 \\
\hline & & Sig. (2-tailed) & 960 & . &, 720 & ,838 \\
\hline & & $\mathrm{N}$ & 32 & 32 & 32 & 32 \\
\hline & \multirow{3}{*}{ BOPO } & Correlation Coefficient &,- 182 & ,066 & 1,000 & ,029 \\
\hline & & Sig. (2-tailed) & ,319 & 720 & . & 873 \\
\hline & & $\mathrm{N}$ & 32 & 32 & 32 & 32 \\
\hline & \multirow{3}{*}{$\begin{array}{l}\text { Unstandardized } \\
\text { Residual }\end{array}$} & Correlation Coefficient &,- 117 & ,038 &, 029 & 1,000 \\
\hline & & Sig. (2-tailed) &, 525 & ,838 &, 873 & \\
\hline & & $\mathrm{N}$ & 32 & 32 & 32 & 32 \\
\hline
\end{tabular}

Source: SPSS Result

The final classical assumption test is autocorrelation test by using Durbin-Watson (DW) test. The result of autocorrelation shows that there is no autocorrelation in this model. From the above result shows that this model had passed the classical assumption test. 
Table 5. The Multicollinearity Result

\begin{tabular}{lcc}
\hline & \multirow{2}{*}{ Model } & \multicolumn{2}{c}{ Collinearity } & Statistics \\
& Tolerance & VIF \\
\hline laku pandai &, 967 & 1,034 \\
Car &, 949 & 1,054 \\
BOPO &, 948 & 1,055 \\
\hline
\end{tabular}

Source: SPSS Result

The result of multiple regressions in Table 6 shows that there is a difference in deposit funds between pre and post the Laku Pandai's program in Bank of BRI Sharia. The positive sign implies that there is a positive relationship between the Laku Pandai's program and deposit funds. It means that the implementation of Laku Pandai's program can increase the movement of deposit funds in Bank of BRI Sharia. The Laku Pandai's program is one of the strategy to expand the networking of banks, especially to attract the new customer and to increase the deposit funds.

The control variables such as: capital adequacy ratio (CAR), operational efficiency ratio (BOPO) had a different result for each other. The capital adequacy ratio had an impact on the deposit funds. The increase in the CAR ratio will be able to increase deposit funds in Bank of BRI Sharia. It implies that the bank should always strengthen the capital; it will attract the customer to increase their deposit in bank. The Laku Pandai's program hopefully can be one of the strategies to strengthen the capital requirement in bank of BRI Sharia.

The variable that had no impact on deposit funds is operational efficiency ratio (BOPO). The data shows that the operational efficiency ratio in bank of BRI Sharia is still above $90 \%$. It means that the bank still not efficiency in banking operations. The Laku Pandai's program is one of the strategies to decrease the operational cost in Bank of BRI Sharia. The Laku Pandai's program can expand the networking with least additional cost.

Table 6. The Multiple Regressions Result

\begin{tabular}{|c|c|c|c|c|c|c|}
\hline \multicolumn{2}{|c|}{ Model } & \multicolumn{2}{|c|}{ Unstandardized Coefficients } & \multirow{2}{*}{$\begin{array}{l}\text { Standardized } \\
\text { Coefficients } \\
\text { Beta }\end{array}$} & \multirow[t]{2}{*}{$\mathrm{t}$} & \multirow[t]{2}{*}{ Sig. } \\
\hline & & B & Std. Error & & & \\
\hline \multirow{4}{*}{1} & (Constant) & 31,238 & 1,554 & & 20,105 & ,000 \\
\hline & DLakuPandai &, 830 & ,243 & 318 & 3,414 & ,002 \\
\hline & CAR &,- 106 & ,013 &,- 777 & $-8,265$ & ,000 \\
\hline & BOPO & ,003 & ,016 & ,015 & ,164 & ,871 \\
\hline
\end{tabular}

Source: SPSS Result

According to the $\mathrm{F}$ test result, it shows that all of the independent variables had an impact on dependent variable. It implies that the variable of Laku Pandai, capital adequacy ratio, and operational efficiency ratio had an impact on deposit funds in Bank of BRI Sharia. The detail of this result can be seen in Table 7 .

The coefficient determination result the value of 0.740 . It means that the independent variables can explain the model about $74 \%$. The variables outside the model can explain in about $26 \%$. The detail of this result can be seen in Table 8 . 
Table 7. The F-test Result

\begin{tabular}{|c|c|c|c|c|c|c|}
\hline \multicolumn{7}{|c|}{ ANOVA $^{a}$} \\
\hline Model & & $\begin{array}{l}\text { Sum of } \\
\text { Squares }\end{array}$ & df & Mean Square & $\mathrm{F}$ & Sig. \\
\hline \multirow{3}{*}{1} & Regression & 22,000 & 3 & 7,333 & 30,378 &, $000^{\mathrm{b}}$ \\
\hline & Residual & 6,759 & 28 & ,241 & & \\
\hline & Total & 28,760 & 31 & & & \\
\hline
\end{tabular}

Source: SPSS Result.

Table 8. The Coefficient Determination Result

\begin{tabular}{|c|c|c|c|c|}
\hline Model & $\mathrm{R}$ & R Square & $\begin{array}{l}\text { Adjusted R } \\
\text { Square }\end{array}$ & $\begin{array}{l}\text { Std. Error of the } \\
\text { Estimate }\end{array}$ \\
\hline 1 &, $875^{\mathrm{a}}$ & ,765 &, 740 &, 49133 \\
\hline
\end{tabular}

Discussion. The Laku Pandai's program is the extension of branchless banking thad had implemented by several banks. In branchless banking program, banking operations are still fully operated by banks. While in the Laku Pandai's program, the operational done by the third party that acting as an agent of the banks. Tandika and Sevriana (2017) stated that the Laku Pandai's program is the adoption of financial inclusive service.

One of the Islamic banks that had implemented the branchless banking is Bank of BJB Sharia, the program called by Jemput Mashlahah program. Adzkia (2014) shows that the Jemput Mashlahah's program had an impact to increase the deposit funds in Bank of BJS Sharia. Nagendra and Shenoy (2011) stated that the inclusive service without branch had a goal to extend the banking networking to the people.

The Laku Pandai's program that had launched by the Financial Service Authority is one of strategies to attract more people in Indonesia to deal with the banking services. The data in Table 1 shows that only 19.6\% of adult people in Indonesia had the account in banks, especially in middle-low people. The Laku Pandai's program is one ways to get closer with the middle-low society. Chege and Nieru (2016) shows that the middle-low people only want to deal with the financial services if they feel secure with the services. Trust is one factor to foster a sense of secure and comfort to the society. The trust factor that can determine the successful of the branchless program, include the Laku Pandai's program (Chaudhary, et al, 2016; Olimov, et al, 2017; Maina and Mwangi M, 2017).

The Laku Pandai's program is one of the solutions to solve one of the weaknesses in the Indonesian Islamic banking industry. According to ngrif (2011) and Rusydiana (2016), one of the weaknesses from Islamic banking in Indonesia is branch's networking. Islamic banking had limited capital to expand the networking; the Laku Pandai's program is one of the strategies to expand the networking with minimum cost. Prasetyo and Sunaryo (2015) conclude that the increase of branch office numbering not always linier with the financial performance of banking industry.

Therefore, the expansion of inclusive banking access is particularly important to improving the competitiveness of the banking industry in Indonesia. The Laku Pandai's programs should also implement by the spin-off's banks. This result is in line with Haribowo (2017). She suggested that the spin-off policy should support by other policies. The Laku Pandai's program is one of the policies that can support the successful of the 
spin-off policy. Spin-off's bank must have limited resources to expand the networking; the Laku Pandai's program can be one of the solutions to decrease their cost.

Inclusive banking services using agents can be an important service in promoting economic growth in a country (Mahmood and Sarker, 2015). Therefore, banks should be able to have a long-term relationship between the organizers of smart conductors and agents. According to Taat (2016) there are four factors that affect long-term cooperation relationship between the organizer bank and the agent, namely: trust, dependency, communication, and commitment.

\section{CONCLUSION}

The empirical result shows that there is a difference in deposit funds between pre and post-Laku Pandai's program. This result implies that this program can expand the access and network of banking services to the communities. The program must accompany by the quality service's improvement. This program will increase the trust and conformity of the user to the transaction using Laku Pandai.

This research recommended several things, such as: first, the Islamic banks, especially for spin-off's banks, should implement the Laku Pandai's program to expand the access and network. Second, the banks should prioritize the safety and convenience factors of customers. Third, the financial service authority (OJK) should give a special treatment for the banks that had implemented this program.

\section{REFERENCES}

Adzkia, M.F. (2014). "Efektivitas Program Layanan Jemput Maslahah dalam Meningkatkan Dana Pihak Ketiga pada PT BJB Syariah Cabang Pajajaran Bogor". Unpublished Bachelor Thesis. Jakarta: UIN Syarif Hidayatullah Jakarta.

Al Arif, M.N.R. (2011). Dasar-Dasar Ekonomi Islam. Solo: Era Adicitra Intermedia.

Anggraeni, N. (2015). "Pengaruh Layanan 3 in 1 Mashlahah (Branchless Banking) terhadap Pertumbuhan Dana Pihak Ketiga (DPK) dan Efisiensi Biaya Operasional Bank pada PT. Bank BJB Syariah". Unpublished Bachelor Thesis. Universitas Islam Bandung. Bandung.

Chaudhary, A.A., et.al. (2016). "Determinants of Users Trust for Branchless Banking in Pakistan". Journal of Internet Banking and Commerce. 21 (1), 1-15.

Chege, K.D. \& Njeru, A. (2016). "Influence of Branchless Banking Services on Saving Practices in Informal Settlements of Kenya: A Case Study of Kibera". International Journal of Science and Research. 5 (10), 1264-1273.

Haribowo, I. (2017). "The Indonesian Islamic Bank's Spin-off: A Study in Regional Development Banks". Al-Iqtishad: Jurnal Ilmu Ekonomi Syariah (Journal of Islamic Economics). 9 (1), 53-68.

Mahmood, R. \& Sarker, S. (2015). "Inclusive Growth Through Branchless Banking: A Review of Agent Banking and Its Impact". Journal of Economics and Sustainable Development. 6 (23), 86-93.

Maina, H.T.M. \& Mwangi M, W. (2017). "Factors Influencing the Uptake of Agency Banking Services by Customers in Commercial Bank in Kenya: A Case of Kenya Commercial Bank". The Strategic Journal of Business and Change Management. 2 (1), 177-197. 
Nagendra, S. \& Shenoy, N. (2011). "Financial Inclusion via Branchless Banking to Extend the Outreach- Case Study of Corporation Bank". International Journal of Advanced Research in Management and Technology. 1 (1), 29-58.

Prasetyo, H. \& Sunaryo, S. (2015). "The Branch Expansion and The Performance of the Banks: The Case of Indonesia". Buleting Ekonomi Moneter dan Perbankan. 18 (1): 85-106.

Rusydiana, A.S. (2016). "Analisis Masalah Pengembangan Perbankan Syariah di Indonesia: Aplikasi Metode Analytic Network Process". Esensi: Jurnal Bisnis dan Manajemen. 6 (2), 237-246.

Sarah, H. (2015). "Dampak Branchless Banking Terhadap Kinerja Keuangan PT. Bank Muamalat Indonesia Tbk". Jurnal Muzaraah. 3 (5), 136 - 157.

Taat, R.M. (2016). “Analisis Variabel yang Mempengaruhi Hubungan Kerjasama Jangka Panjang Antar Bank Penyelenggara Laku Pandai dan Agen". Jurnal Ilmiah Mahasiswa FEB Universitas Brawijaya. 4 (2), 201-210.

Tandika, D. \& Sevriana, L. (2017). "Adopsi Terhadap Inovasi: Kajian Konseptual Implementasi Program Laku Pandai Pada Layanan BRILink". Performa: Jurnal Manajemen dan Bisnis. 14 (1), 53-64

Olimov, S. et al. (2017). "Performance of Depositor Fund: A Lesson From Indonesian Islamic Banking System”. Etikonomi. 16 (1), 53-70. 